\title{
Utilization of Whey and Permeate to Produce Single Cell Protein by Using some Yeasts
}

\author{
Gomaa, M. S. ${ }^{1}$; M. M. Abo-Srea ${ }^{1}$; Eman L. Mostafa ${ }^{2}$ and Doaa M. Fathy ${ }^{2}$ \\ ${ }^{1}$ Dairy Sci. Dept., Faculty of Agriculture, Mansoura Univ. \\ ${ }^{2}$ Anim. Prod. Res. Institute, Agric. Res. Cent., Giza.
}

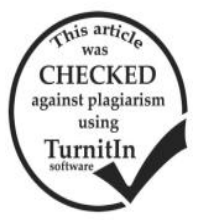

\begin{abstract}
The aim of work was to utilize the by-products such as whey or milk permeate to produce single cell protein and to reduce the environmental pollution from three individual yeast strains (Kluyveromyces fraglis, Kluyveromyces lactis or Saccharomyces cervesiae). All of these were cultivated at the optimum condition for 48 and $96 \mathrm{hr}$ by using whey, permeate or YM as media. The obtained results indicated that Kluyveromyces fraglis achieved the highest growth $\left(22 \times 10^{6} \mathrm{cfu} / \mathrm{ml}\right) \mathrm{on}$ the whey after $96 \mathrm{hr}$, and the yield of biomass (2.5 gm/L) after $96 \mathrm{hr}$., followed by Kluyveromyces lactis and Saccharomyces cervesiae. K. fraglis achieved the highest value of BOD $(58.1 \mathrm{mg} / \mathrm{L})$ on the permeate after $96 \mathrm{hr}$, and the removal and consumed lactose (37\%) on permeate after $96 \mathrm{hr}$.
\end{abstract}

Keywords : Whey, Permeate, S.C.P, Kluyveromyces fraglis, Kluyveromyces lactis or Saccharomyces cervesiae, BOD. Abbreviations :S.C.P : Single cell protein. BOD : Biochemical oxygen demand.

\section{INTRODUCTION}

Whey is the aqueous fraction of milk generated as a by-product of cheese manufacturing which is produced in large amounts, the percentage of lactose in cheese whey about 3-8 \% (Speer, 1998). While, milk permeate is a more recent by-product from ultrafiltration (UF) process of milk when membrane technology is employed to manufacture (UF) process of milk when membrane technology is employed to manufacture cheese.

Diposal of whey and milk permeate using any traditional methods could be a source for environment of pollution that increase the BOD as a result of the presence of tremendous concentration of organic substances. Also, because these by-products contain high level of nitrogen, phosphorus and some other materials, it must be managed carefully when used for land irrigation. Besides whey and milk permeate can cause serious problems even when dumped directly into municipal sewage system because of their high BOD. The use of whey for the production of yeast biomass has the advantages that it is a simple treatment process, and the final discharge of the whey and milk permeate are facilitated since the pollutant load is significantly reduced and the whey and milk permeate lactose are converted into yeast biomass by using yeasts such as kluyveromyces, candidu and trichosooron as they are naturally able to metabolize lactose (Mansour et al., 1993).

For this reason in our search we used their Kluyveromyces fraglis, Kluyveromyces lactis or Sacharomyces cervesiae to produce single cell protein (biomass) by cultivate all of them on whey, permeate or YM media.

\section{MATERIALS AND METHODS}

YM Broth : was used for the activation of different strains. It consists of: Glucose $10 \mathrm{~g} / \mathrm{L}$, Peptone $5 \mathrm{~g} / \mathrm{L}$, Maltextract $3 \mathrm{~g} / \mathrm{L}$ and Yeast extract $3 \mathrm{~g} / \mathrm{L}$.Permeate of buffalo milk was obtained from Animal Production Research Institute.Whey of Mozzarella cheese being used was brought from Faculty of Agriculture, Cairo University. Kluveromyces fraglis (Marxians) (NRRY-
1109), Kluveromyces lactis (DSM70800) and Sacsharomyces cervesia were obtained from the Egyptian Microbial Culture Collection (E.M.C.C) MIRCEN, Ain Shams University (Cairo). Ammonium sulphate $(0.8 \mathrm{gm} /$ liter), Yeast extract $(0.2 \%)$ and Potassium nitrate $(0.4 \mathrm{gm}$ / liter) were purchased from the market. The three above source of nitrogen were added individually to the filtrate of whey or permeate to act as a source of nitrogen.

Lactose was determined according to Perry and Doan (1950). $\mathrm{pH}$ values were determined using lab $-\mathrm{pH}$ meter (G. Schott, Germany). Titratable acidity was determined according to Ling (1963) as lactic acid percentage. Biomass was estimated by centrifuging $25 \mathrm{ml}$ of the permeate, YM or whey media after proper mixing using sigma 301 centrifuge at $5000 \mathrm{rpm}$ for $10 \mathrm{~min}$. the supernatant was discarded; the yeast cell residue (biomass) was weighed (Capoor and Singh, 1985). This weight consider as a wet weight, then the biomass were dried in the oven at $80{ }^{\circ} \mathrm{C}$ for $24 \mathrm{hr}$. Biochemical oxygen demand (BOD) was determined before and after fermentation, using the method reported by APHA (1998) calculating by the equation of :

$$
\text { BOD } 5 \mathrm{mg} / \mathrm{L}=\frac{\text { D1 }- \text { D2 }}{-\cdot----}
$$

Where :

$D 1=D 0$ of diluted sample immediately after preparation, $\mathrm{mg} / \mathrm{L}$.

$D 2=D 0$ of diluted sample after 5 days incubation at $20^{\circ} \mathrm{C}, \mathrm{mg} / \mathrm{L}$.

For the preparation of the cultures YM Broth medium was distributed in $10 \mathrm{ml}$ pyrex tubes and sterilized. Sterilized loup was used to transfer the strains of yeasts individually into the tubes then well stirred and incubated at $32{ }^{\circ} \mathrm{C}$ for $48 \mathrm{hr}$.

The turbidity and sedimentations refer to the activity of the yeast. The activated strains were kept at refrigerator at $4 \pm 2{ }^{\circ} \mathrm{C}$ for using at the same day. The absorbance was measured at $650 \mathrm{~nm}$ as recommend by Ezzat and El- Shafei (1988) using Shimadzn (UVvisible) spectrophotometer-experiments.Malt extract agar medium was used to determine the yeast cell count as recommended by the American Public Health Association (1992).

For the preparation of whey, the $\mathrm{pH}$ of the whey was adjusted to ph 4.5 , then flasks were heated in water bath 
at $90 \pm 2{ }^{\circ} \mathrm{C}$ for two hours, then filtrated to get rid of whey proteins.

The $\mathrm{pH}$ of permeate was adjusted to 4.5 then heated in water bath at $90 \pm 2{ }^{\circ} \mathrm{C}$ then cooled and filtrated, finally it sterilize at $121{ }^{\circ} \mathrm{C}$ for $15 \mathrm{~min}$.

To study the effect of medium on the activity of each of individual strain, $K$. fraglis grown on either whey or permeate fortified with ammonium sulphate at

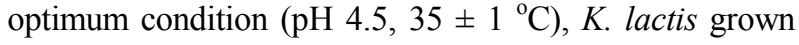
on whey or permeate supplemented with yeast extract at optimum conditions (pH 4.5 and $30{ }^{\circ} \mathrm{C}$ ) while Saccharomyces cervesia grown on whey or permeate supplemented with potassium nitrate under optimum conditions ( $\mathrm{pH} 6.6$ at $30{ }^{\circ} \mathrm{C}$ ). Control was done by growing $K$. fraglis, $K$. lactis or $S$. cervesiae on YM medium at the optimum conditions of all of them.
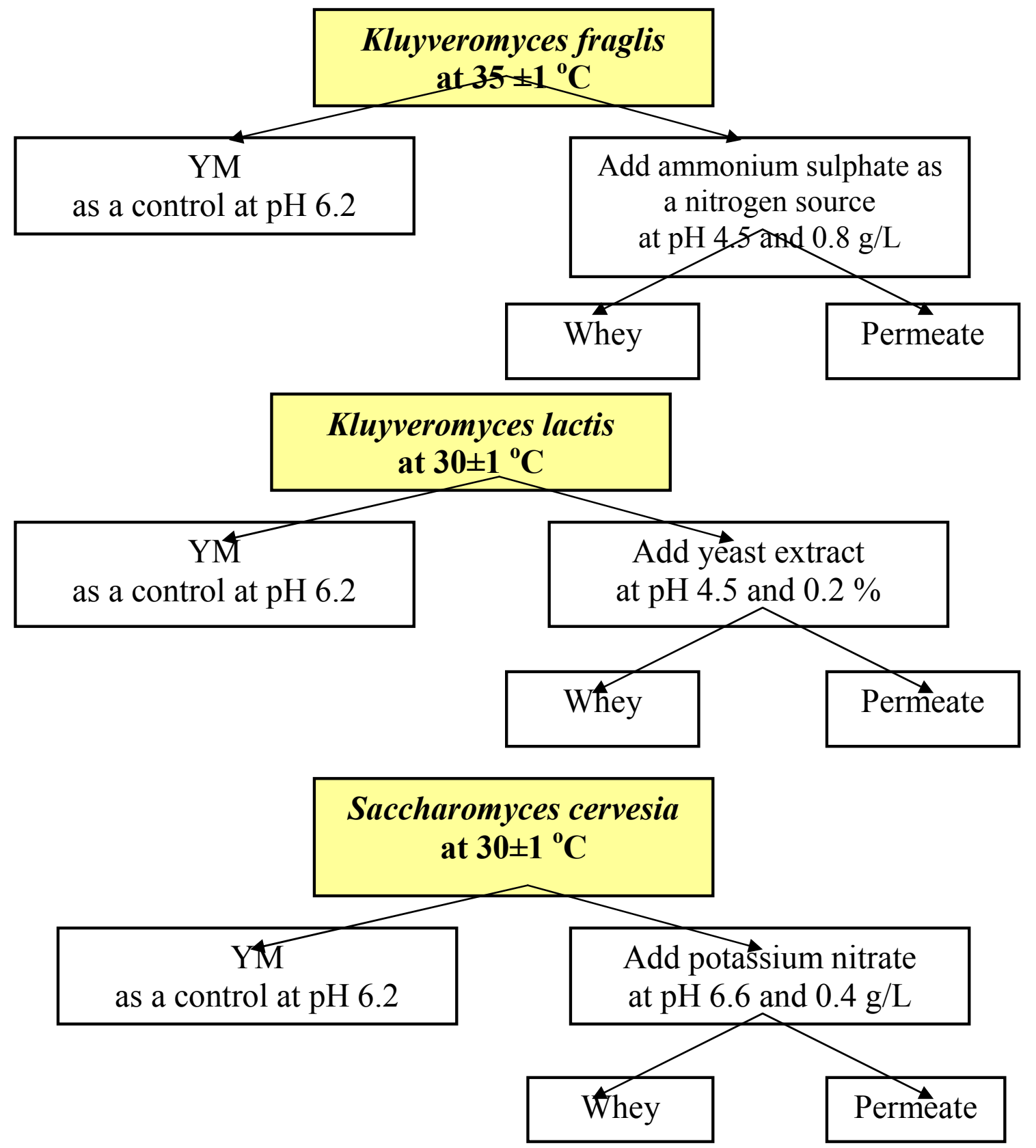

\section{RESULTS AND DISCUSSION}

It is clear that the acidity \% ranged between $(0.11$ $\%)$ in YM medium and $(0.42 \%)$ in whey, and it decreased after $96 \mathrm{hr}$ in all different media Table (1). The $\mathrm{pH}$ was parallel to acidity. These results due to $K$. fraglis produce amount of alchole which changes the acidity. These results agree with Abo-EL-Einin (2006), the growth of $K$. fraglis in permeate increased the $\mathrm{pH}$ during fermentation, then it decreased in the end of fermentation (Foad, 2006) and Abo-EL-Einin (2006).

The same Table and Fig. (1) show that the consumed lactose in different media ranged between (12 $\%)$ in YM medium and (23\%) in permeate after $48 \mathrm{hr}$, then it increased after $96 \mathrm{hr}$. Permeate recorded the highest value of $37 \%$, while YM media recorded the lowest of $24 \%$. These results agree with Gholson and Gough (1980), who stated that when treated the sweet Cheddar type whey with $K$. fraglis, it resulted in greater 
than $90 \%$ of the lactose, Singh and Neelakantan (1989) reported that $\mathrm{K}$. fraglis 3217 and S. fraglis had higher lactose utilization than $C$. pseudotropicalis. Results in Table (1) and Fig. (2) showed considerable increase in the BOD after 48 and $96 \mathrm{hr}$, the permeate recorded the highest value $(58.1 \mathrm{mg} / \mathrm{L})$ and YM medium achieved the low value $(31.3 \mathrm{mg} / \mathrm{L})$. These results agree with Kasiem (2000); Omar (2009) and Meera Babu et al. (2014) who found that Kluyveromyces fraglis was effective in BOD removal. Reduction in BOD level was obtained by Capoor and Singh (1995), by S. fraglis and K. fraglis, respectively, while lower value was observed for $C$. pseudotropicalis.

Table 1. Effect of different media on some chemical parameters of $K$. fraglis at optimum condition for 48 and $96 \mathrm{hr}$.

\begin{tabular}{lccccccccc}
\hline & \multicolumn{1}{c}{ Parameters } \\
Media & \multicolumn{1}{c}{$\mathbf{p H}$} & \multicolumn{4}{c}{ Acidity } & \multicolumn{3}{c}{ Consumed } & \multicolumn{2}{c}{ BOD } \\
& $\mathbf{4 8}$ & $\mathbf{9 6}$ & $\mathbf{4 8}$ & $\mathbf{9 6}$ & $\mathbf{4 8}$ & $\mathbf{9 6}$ & $\mathbf{4 8}$ & $\mathbf{9 6}$ \\
& $\mathbf{h r}$ & $\mathbf{h r}$ & $\mathbf{h r}$ & $\mathbf{h r}$ & $\mathbf{h r}$ & $\mathbf{h r}$ & $\mathbf{h r}$ & $\mathbf{h r}$ \\
\hline YM & 4.43 & 5.21 & 0.11 & 0.05 & 12 & 24 & 20.5 & 31.3 \\
medium & & & & & & & & \\
Whey & 5.75 & 5.82 & 0.42 & 0.20 & 20 & 33 & 45.11 & 54.2 \\
Permeate & 3.75 & 5.27 & 0.43 & 0.12 & 23 & 37 & 55.12 & 58.1 \\
\hline
\end{tabular}

BOD $=$ Biological oxygen demand.

YM medium : (Yeast - Malt - Pepton - Glucose broth medium)

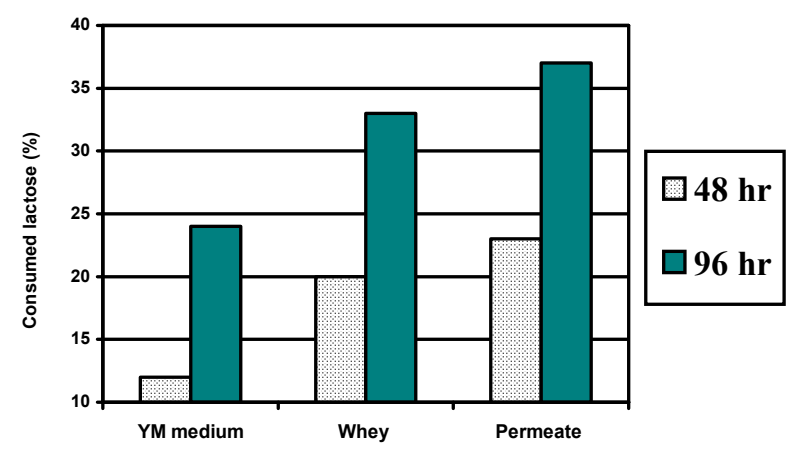

Type of media

Fig. 1. Effect of different medias on decreased of lactose.

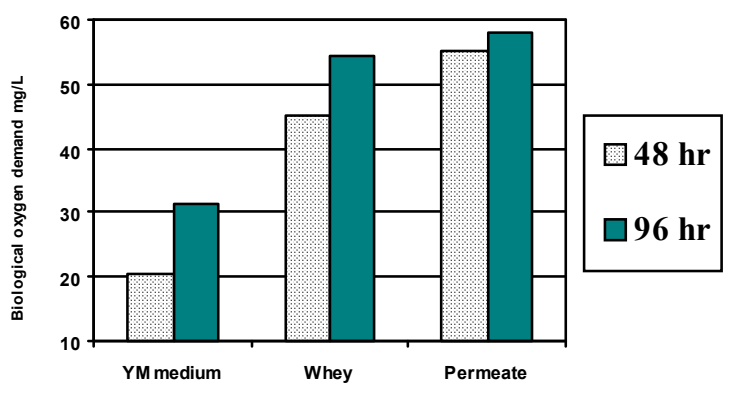

Type of media

Fig. 2. Effect of different medias on BOD (Biochemical Oxygen Demand).
Table (2) shows that effect of different media on turbidity. It ranged between (0.304) in YM medium and (0.991) in whey after $(48 \mathrm{hr})$. Turbidity increased in all media after $96 \mathrm{hr}$, permeate recorded the highest value (1.345) while YM medium achieved the lowest value (0.590). In the same Table and Fig. (3) showed that biomass as dry weight increased, it ranged between $(0.83 \mathrm{gm} / \mathrm{L})$ in $\mathrm{YM}$ medium and $(1.9 \mathrm{gm} / \mathrm{L})$ in whey after $(48 \mathrm{hr})$, then increased after $96 \mathrm{hr}$ in all different media. The whey recorded the highest value of 2.5 $\mathrm{gm} / \mathrm{L}$ after $96 \mathrm{hr}$, but YM medium achieved the lowest of 1.9. These results agree with Capoor and Singh (1986), who found that max. biomass yield of Kluyveromyces fraglis and Saccharomyces fraglis in clarified paneer whey after incubation for $72 \mathrm{hr}$ at $30{ }^{\circ} \mathrm{C}$ were 7.93 and 10.70, respectively and Demerdash and Abd EL-Ghany (1998) reported that the highest amount of cellular biomass from whey was achieved by $K$. fraglis $(11.6 \mathrm{~g} / \mathrm{L})$.

Results in the same Table and Fig. (4) indicated that considerable increase in total viable count after 24 until $72 \mathrm{hr}$, then it decreased after $96 \mathrm{hr}$. Whey recorded the highest value $\left(22 \times 10^{6}\right.$ C.FU) at $72 \mathrm{hr}$, while the YM media recorded the lowest value $(13 \mathrm{x}$ $10^{6}$ ) C.FU after $72 \mathrm{hr}$, this is due to consume the mineral and all nutrients in medium by the strains.

Table 2. Effect of different media on turbidity, biomass and viable count of Kluyveromyces fraglis for 48 and $96 \mathrm{hr}$.

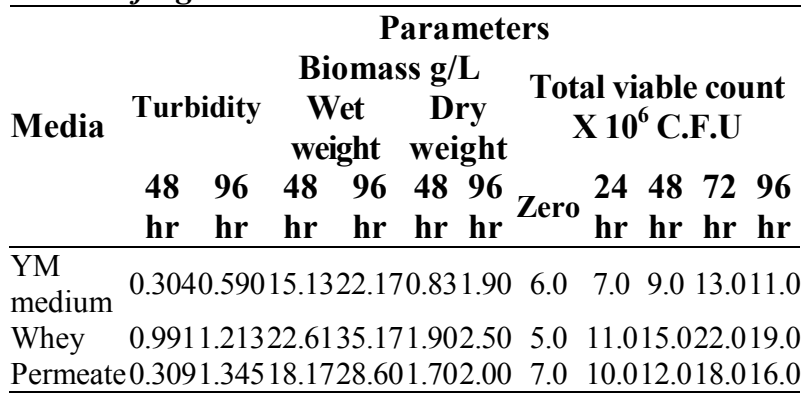

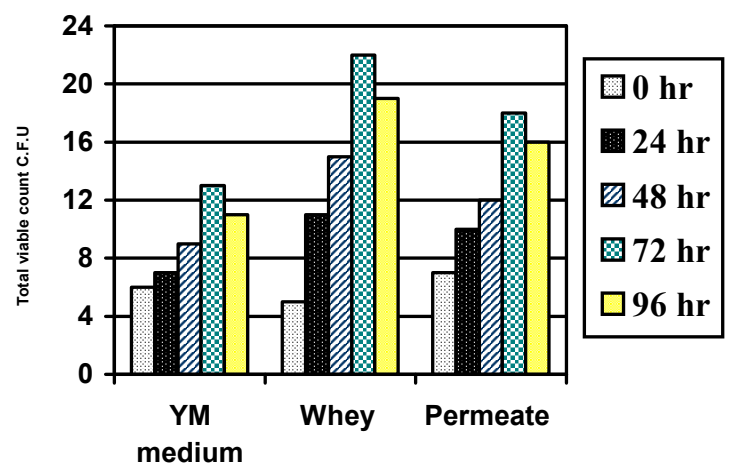

Type of media

Fig. 3. Effect of different medias on total viable count $\mathrm{cfu} / \mathrm{ml}$. 


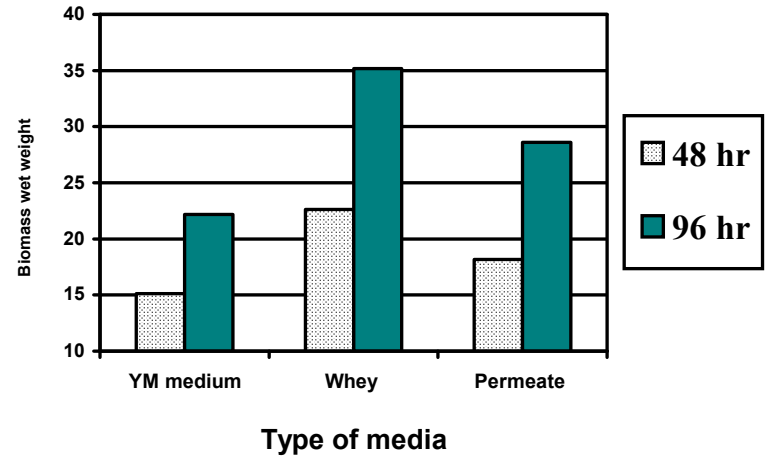

Fig. 4. Effect of different medias on biomass.

Table (3) shows that the acidity ranged between (0.03) in YM medium and (0.37) in whey after $48 \mathrm{hr}$, and decreased after $96 \mathrm{hr}$ in all different media. The $\mathrm{pH}$ run in opposite parallel to acidity. These results due to $K$. lactis produce amount of alchole and this amount of alchole change the acidity. The same table and Fig. (5) shows consumed lactose in different media during the incubation time it ranged between $(12 \%)$ in permeate and $(17 \%)$ in whey after $48 \mathrm{hr}$ then it increase after 96 $\mathrm{hr}$, permeate recorded the highest value while YM medium achieved the lowest value (22 \%), which agreed with Abo-EL-enin (2006). Fig. (6) showed that the BOD increased after $96 \mathrm{hr}$. It could also be observed the highest value $(39.5 \%)$ in permeate, while the lowest was recorded in YM medium (19.3\%) after $96 \mathrm{hr}$. This result agreed with Kassiem (2000).

Table 3.Effect of different media on some chemical parameters of Kluyveromyces lactis at optimum condition for 48 and $96 \mathrm{hr}$.

\begin{tabular}{|c|c|c|c|c|c|c|c|}
\hline \multirow{3}{*}{ Media } & \multirow{2}{*}{\multicolumn{2}{|c|}{ pH }} & \multicolumn{4}{|c|}{ Parameters } & \multirow[b]{2}{*}{$\underset{\mathrm{mg} / \mathbf{L}}{\mathbf{B O D}}$} \\
\hline & & & $\underset{(\%)}{A c i}$ & $\begin{array}{l}\text { idity } \\
\text { o) }\end{array}$ & $\begin{array}{l}\text { Cons } \\
\text { lactos }\end{array}$ & $\begin{array}{l}\text { umed } \\
\text { e }(\%)\end{array}$ & \\
\hline & $\begin{array}{l}48 \\
\text { hr }\end{array}$ & $\begin{array}{l}96 \\
\text { hr }\end{array}$ & $\begin{array}{l}48 \\
\mathrm{hr}\end{array}$ & $\begin{array}{l}96 \\
\text { hr }\end{array}$ & $\begin{array}{l}48 \\
\text { hr } \\
\end{array}$ & $\begin{array}{l}96 \\
\text { hr } \\
\end{array}$ & $\begin{array}{ll}48 & 96 \\
\text { hr } & \text { hr }\end{array}$ \\
\hline $\begin{array}{l}\text { YM } \\
\text { medium }\end{array}$ & 5.75 & 5.73 & 0.03 & 0.03 & 16.0 & 22.0 & 13.119 .3 \\
\hline $\begin{array}{l}\text { Whey } \\
\text { Permeate }\end{array}$ & $\begin{array}{l}4.45 \\
4.46\end{array}$ & $\begin{array}{l}5.35 \\
4.51\end{array}$ & $\begin{array}{l}0.37 \\
0.15\end{array}$ & $\begin{array}{l}0.14 \\
0.13\end{array}$ & $\begin{array}{l}17.0 \\
12.0\end{array}$ & $\begin{array}{l}25.0 \\
30.0\end{array}$ & $\begin{array}{ll}28.2 & 35.4 \\
26.1 & 39.5\end{array}$ \\
\hline
\end{tabular}
BOD = Biological oxygen demand.

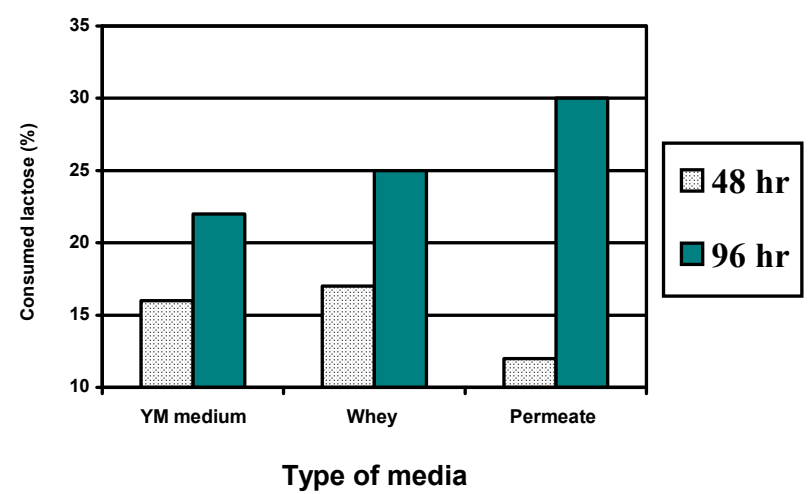

Fig. 5. Effect of different medias on decreased of lactose.

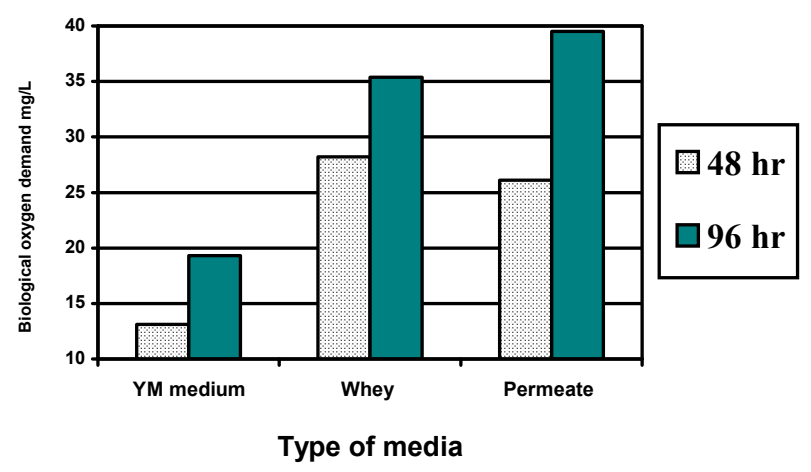

Fig. 6. Effect of different medias on BOD (Biochemical Oxygen Demand).

Table (4) shows that the turbidity ranged between 0.640 in YM medium and 1.012 in whey after $48 \mathrm{hr}$. It increased in all media after $96 \mathrm{hr}$ as whey recorded the highest value of (1.038), while YM medium achieved the lowest $(0.778)$. The biomass as dry weight ranged between $0.59 \mathrm{gm} / \mathrm{L}$ in YM medium and $1.6 \mathrm{gm} / \mathrm{L}$ in permeate after $48 \mathrm{hr}$ then it increase after $96 \mathrm{hr}$ in all different media. Whey recorded the highest value (2.10 $\mathrm{gm} / \mathrm{L}$ ) while, YM medium recorded lowest value (1.7 $\mathrm{gm} / \mathrm{L}$ ). These results agree with Murad et al. (1992) and Hassan et al. (2004). Also, in the same Table it could be indicated that considerable increase in total viable count after $24 \mathrm{hr}$ until $72 \mathrm{hr}$, then decreased after $96 \mathrm{hr}$. The whey recorded the highest value $\left(19 \times 10^{6} \mathrm{CFU}\right)$, while the YM medium recorded the lowest value $\left(15 \times 10^{6}\right.$ CFU).

Table 4. Effect of different media on turbidity, biomass and viable count of Kluyveromyces lactis at optimum condition for 48 and $96 \mathrm{hr}$.

\begin{tabular}{|c|c|c|c|c|c|c|c|}
\hline \multirow{3}{*}{ Media } & \multicolumn{7}{|c|}{ Parameters } \\
\hline & Turbidity & \multirow{2}{*}{ 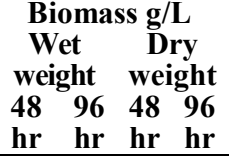 } & \multicolumn{5}{|c|}{$\begin{array}{c}\text { Total viable count } \\
\text { X } 10^{6} \text { C.F.U }\end{array}$} \\
\hline & $\begin{array}{l}96 \\
\text { hr }\end{array}$ & & Zero & $\begin{array}{l}24 \\
\text { hr }\end{array}$ & $\begin{array}{l}48 \\
\mathrm{hr}\end{array}$ & $\begin{array}{l}72 \\
\mathrm{hr}\end{array}$ & $\begin{array}{l}96 \\
\text { hr }\end{array}$ \\
\hline medium & 0.6400 .778 & 9.6119 .80 .591 .70 & 4.0 & & & & \\
\hline $\begin{array}{l}\text { Whey } \\
\text { Permeate }\end{array}$ & $\begin{array}{l}1.0121 .038 \\
0.9171 .009\end{array}$ & $\begin{array}{l}2.1627 .31 .502 .10 \\
4.8125 .21 .601 .90\end{array}$ & $\begin{array}{l}6.0 \\
8.0\end{array}$ & $\begin{array}{c}9.01 \\
11.01\end{array}$ & & & \\
\hline
\end{tabular}

Table (5) shows that (T.A) titratable acidity ranged between (0.02) in YM medium and (0.27) in whey after $48 \mathrm{hr}$, it decreased after $96 \mathrm{hr}$ in all different media. The $\mathrm{pH}$ ran in an opposite trend to acidity. The consumed lactose in different media during the incubation time ranged between $(15 \%)$ in whey and (18 $\%$ ) in YM medium after $48 \mathrm{hr}$, then it increased after 96 hr (Table 5). YM medium recorded the highest value (27\%) while sweet whey recorded lowest value (23\%). These results agree with Barraduio et al. (1981); Singh and Neelakantan (1989) and Compagno et al. (1995). The BOD after $48 \mathrm{hr}$ and $96 \mathrm{hr}$ whey recorded the highest value $(38.5) \mathrm{mg} / \mathrm{L}$ while YM media recorded the low value (33.4) mg/L after $96 \mathrm{hr}$ (Table 5). 
Table 5. Effect of different media on some chemical parameters of Saccharomyces cervesiae at optimum condition for 48 and $96 \mathrm{hr}$.

\begin{tabular}{lcccccccc}
\hline & \multicolumn{8}{c}{ Parameters } \\
Media & $\mathbf{p H}$ & \multicolumn{4}{c}{$\begin{array}{c}\text { Acidity } \\
\mathbf{( \% )}\end{array}$} & \multicolumn{2}{c}{ Consumed } & \multicolumn{2}{c}{ BOD } \\
& $\mathbf{4 8}$ & $\mathbf{9 6}$ & $\mathbf{4 8}$ & $\mathbf{9 6}$ & $\mathbf{4 8}$ & $\mathbf{9 6}$ & $\mathbf{4 8}$ & $\mathbf{9 6}$ \\
& $\mathbf{h r}$ & $\mathbf{h r}$ & $\mathbf{h r}$ & $\mathbf{h r}$ & $\mathbf{h r}$ & $\mathbf{h r}$ & $\mathbf{h r}$ & $\mathbf{h r}$ \\
\hline YM medium & 6.09 & 5.40 & 0.02 & 0.08 & 18.0 & 27.0 & 23.1 & 33.4 \\
Whey & 5.90 & 4.73 & 0.27 & 0.35 & 15.0 & 23.0 & 30.2 & 38.5 \\
Permeate & 5.70 & 5.55 & 0.11 & 0.25 & 16.0 & 25.0 & 22.0 & 34.7 \\
BOD = Biological oxygen demoned. & & & & \\
\hline
\end{tabular}

Table (6) indicated the effect of different media on turbidity. It ranged between $(0.305)$ in permeate and (0.720) in whey after $48 \mathrm{hr}$ and it increased in all media after $96 \mathrm{hr}$, YM medium recorded the highest value (0.991) and permeate achieved a lowest value after $96 \mathrm{hr}$. These results were agree with Omar (2009). In the same Table the biomass as dry weight ranged between $(1.6 \mathrm{gm} / \mathrm{L})$ in permeate and $(2 \mathrm{gm} / \mathrm{L})$ in YM medium after $48 \mathrm{hr}$ then it increase after $96 \mathrm{hr}$ in all different media. The whey recorded the highest value $(2.3) \mathrm{gm} / \mathrm{L}$ permeate recorded the lowest value $(2 \mathrm{gm} / \mathrm{L})$ after $96 \mathrm{hr}$. These results agree with Barraquio et al. (1981) and Compagno et al. (1995).

Table 6. Effect of different media on turbidity, biomass and viable count of $S$. cervesia at optimum condition for 48 and $96 \mathrm{hr}$.

\begin{tabular}{|c|c|c|c|c|c|c|c|c|c|}
\hline \multirow{3}{*}{ Media } & \multicolumn{9}{|c|}{ Parameters } \\
\hline & \multicolumn{2}{|c|}{ Turbidity } & \multicolumn{2}{|c|}{$\begin{array}{l}\text { Biomas } \\
\text { Wet } \\
\text { weight }\end{array}$} & \multirow{2}{*}{$\begin{array}{c}\text { s g/L } \\
\text { Dry } \\
\text { weigh } \\
\text { t } \\
4896 \\
\text { hr hr } \\
\end{array}$} & \multicolumn{4}{|c|}{$\begin{array}{l}\text { Total viable count } \\
\text { X } 10^{6} \text { C.F.U }\end{array}$} \\
\hline & $\begin{array}{l}48 \\
\mathrm{hr}\end{array}$ & $\begin{array}{l}96 \\
\mathrm{hr}\end{array}$ & $\begin{array}{l}48 \\
\text { hr }\end{array}$ & $\begin{array}{l}96 \\
\text { hr }\end{array}$ & & $\begin{array}{c}\text { Zer } \\
\text { o }\end{array}$ & $\begin{array}{l}24 \\
\text { hr }\end{array}$ & $\begin{array}{l}48 \\
\text { hr }\end{array}$ & $\begin{array}{ll}72 & 96 \\
\text { hr } & \text { hr } \\
\end{array}$ \\
\hline $\begin{array}{l}\text { YM } \\
\text { medium }\end{array}$ & 0.492 & & 195 & 23.11 & 2.02 .2 & 8.0 & 10.0 & 12.0 & 19.015 .0 \\
\hline Whey & & & & & & 5.0 & & & \\
\hline Permeate & 0.305 & 0.479 & & 203 & 1.62 .0 & 7.0 & & 11. & 17.011 .0 \\
\hline
\end{tabular}

In same Table we indicated increasing in total viable count after $24 \mathrm{hr}$ until $72 \mathrm{hr}$ then it decreased after $96 \mathrm{hr}$, the whey recorded the highest value $(20 \mathrm{x}$ $10^{6}$ C.F.U) while permeate recorded the low value $(17 \mathrm{x}$ $10^{6}$ C.F.U).

\section{REFERENCES}

A.P.H.A. (1992). Standard methods for the examination of Water and Wastewater. The $20^{\text {th }}$ ed., New York, N4.

Abou EL-Enein, Karima A.M. (2006). Utilization of cheese industry wastes in the production of yeast and its derivatives. Ph.D. Thesis, Fac. of Agric., Ain Shams Univ.

American Public Health Association (1992). Standard methods for the examination of dairy products, Broadway New York, N.Y., U.S.A.
Babu, M.; Raj, S.P.; Nirmala, C.B.; Deccaraman, M. and Sagadevan, E. (2014). Production of single cell protein using Kluveromyces marxianus isolated from paneer whey. Inter. J. of Bio. and Advance Res., 5(5): 255257.

Barraquio, V.L.; Silverio, L.G.; Revilleza, R.P. and Fernandez, W.L. (1981). Production of protein rich animal feed supplement from cheese whey. Milchwissenschaft, 36(4): 209-211.

Campeanu, G.H.; Vamanu, A.; Popa, O.; Dumitru, I.F.; Elena, S.; Tatiana, V, et al. (2002). Biotechnological studies concerning the obtaining of biomass with probiotic role from yeasts and bacteria. Roum Biotechnol. Lett., 7: 795-802.

Capoor, A.K. and Singh, K. (1985). Fermentation of whey by lactose utilizing yeast for S.C.P. production and BOD reduction. Indian J. of Dairy Sci., 38(1): 15-17.

Compagno, C.; Porro, D.; Smeraldi, C. and Ranzi, B.M. (1995). "Fermentation of whey and starch by transformed Sacchromyces cerevisiae cells". Applied Microbiol. and Biotech., 43(5): 822-825.

Demerdash, M.A. and Abd El-Ghany, I.H.I. (1998). "Fermentation and growth kinetics of some yeast isolates on salted whey". Egypt. J. Appl. Sci., 13(12): 539-550.

Ezzat, N.; EL-Soda, M. and EL-Shafei, H. (1988). The cellbound proteinase system of Lactobacillus caseipurification and characterization. Food Microbiol., 6: 327.

Farhoodi, S.; Moosavi-Nasab, M. and Nasiri, L. (2008). Single Cell Protein (SCP) production from UF cheese whey by Kluveromyces marxianus. In: $18^{\text {th }}$ National Congress on Food Technology Mashahd, 2008 Oct. 15-16; Iran.

Gholson, J.H. and Gough, R.H. (1980). Yeast that utilize lactose in whey. Louisiana Agriculture, 23(3): 91-21.

Hassan, M.; Iraj, N. and Manoochehr, T. (2004). Improvement of S.C.P. production and BOD removal of whey with mixed yeast culture. Electronic J. of Biotech., 7: 249254.

Ling, E.R. (1963). A Text Book of Dairy Chemistry. Vol. 2, Practical ${ }^{\text {rd }}$ ed. Chapman and Hall, LTD, London.

Mansour, M.H.; Ghaly, A.E.; Ben-Hassan, R.M. and Nassar, M.A. (1993). Modeling batch production of single cell protein from cheese whey. I: Kluveromyces fraglis growth. Appl. Biochem. and Biotech., 43(1): 173.

Murad, H.A.; Abd-El-Ghani, S. and El-Shenawy, K. (1992). "Bioconversion of whey permeate into Kluveromyces lactis biomass". Egypt. J. of Dairy Sci., 20(2): 261271.

Omar, Sabrien A.I. (2009). Studies on color elimination of molasses by some microorganisms. Ph.D. Thesis, Fac. of Agric., Mansoura Univ.

Perry, N.A. and Doan, F.J. (1950). Picric acid method for the simultaneous determination of lactose and sucrose in dairy products. J. Dairy Sci., 33(1): 176.

Singh, K. and Neelakantan, S. (1989). Amino acid composition of yeast single cell protein grown on paneer whey. J. of Dairy Res., 56(5): 813-815.

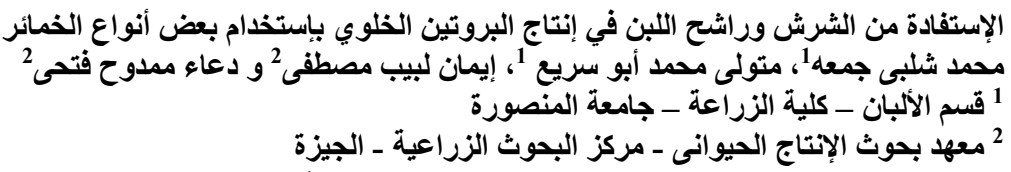

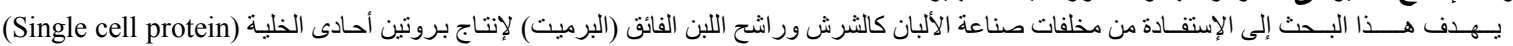

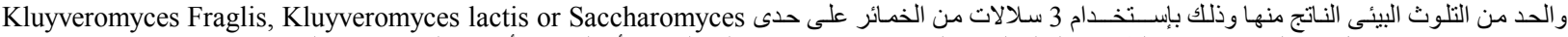

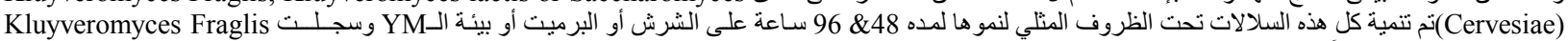

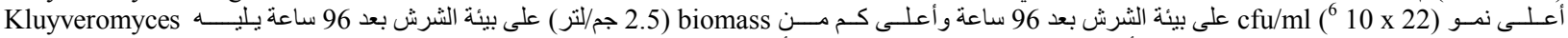

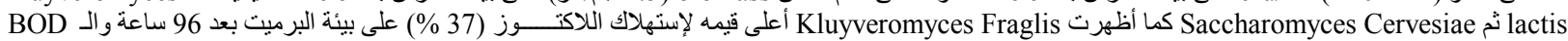
(58.1) (Biochemical oxygen demand) 